\title{
Clifford Thomas Morgan: Psychonomic Society's First Chairman
}

\author{
W. R. GARNER \\ Yale University, New Haven, Connecticut 06520
}

Clifford Thomas Morgan: born July 21, 1915, in Minotola, New Jersey; died February 12, 1976, in Austin, Texas. These are the minimum facts about a man who was truly unique in his contribution to experimental psychology in general, and to this Society in particular. His contribution was not unique because of a single skill which was used to produce enduring consequences; rather, it was unique because of its many facets. Cliff Morgan made his contributions with a range of skills and abilities which few of us are privileged to possess. Arthur Melton, in his statement at Cliff's memorial service, called him a Renaissance man because of the breadth of his activities, and I think that is a rather good way to characterize him.

I shall comment on Cliff Morgan's many different facets, but it may help if first I give you a quick overview of his life and career so that you may see the changes in his activities as they relate to the change in his location. His early years were spent in New Jersey, where he grew up in a strongly religious home, religion of the protestant fundamentalist and evangelical form. While I am not going to attempt to assay the effect of his early religious training on his later life, it is evident to all of us who knew him well that some aspects of this training remained with him throughout his life. When it came time to go to college, he made his decision to choose Maryville College in Tennessee on very practical grounds of the kind that frequently influenced his later decisions: It was a religiously oriented college and, being in the South, was considerably cheaper. So off he went to college, but after two years lost the religion which was one of his reasons for choosing Maryville in the first place. And in preview fashion, his loss of religion was done with considerable inner turmoil, the kind of turmoil which characterized many of his later changes in career.

However, it was at Maryville that Paul Fields got

In preparing this address, I have needed to call on many people for help in contributing information about him, and I hereby thank: Geraldine Stevens, Jean Morgan, Edwin Newman, Eliot Stellar, J. C. R. Licklider, David Grant, Frederick Mote, Howard Kendler, Janet Spence, Abram Amsel, Arthur Melton, David Ehrenfreund, Sharon Tarver, and, most especially, William Verplanck. This memorial address was presented at the Seventeenth Annual Meeting of the Psychonomic Society, November 1976, St. Louis, Missouri.
Cliff interested in experimental psychology, to the point where he decided to make it his career. He entered the University of Rochester in 1936, intending to study with Leonard Carmichael, who had just come to Rochester from Brown. But Carmichael went on to become President of Tufts College before Cliff finished his degree, so he actually did his dissertation with Elmer Culler, although Carmichael always considered Cliff as one of "his boys." It was an exciting period at Rochester in those days, with people like W. D. Neff, J. C. R. Licklider, William Kappauf, Leonard Mead, John Kennedy, and Paul Fitts being fellow graduate students.

Morgan's first academic position was as Instructor at Harvard, starting in 1939. He formally remained at Harvard only until 1943, but because of wartime perturbations, he actually remained in close contact with Harvard for two more years. He had accepted appointment as Assistant Professor at Johns Hopkins University in 1943, but was put on leave until the end of the war. During this period he was a Technical Aide in the Office of Scientific Research and Development, a position that required him to coordinate various wartime research activities, including those of $\mathrm{S}$. S. Stevens' Psycho-Acoustic Laboratory at Harvard. He moved to Washington in 1943, but was at Harvard on a regular weekly basis for the rest of the war.

He actually moved to Baltimore to take up his duties there in early 1946, and he remained at Johns Hopkins until 1959, having become Associate Professor in 1946 and Professor in 1948. He became a Fellow (an honorary title) at Johns Hopkins in 1957, and retained that title for three years, although he actually moved in 1959 to the University of Wisconsin, where he stayed for the next three years. In 1962 he moved to the University of California at Santa Barbara, where he remained for several more years. Then in 1968 he moved to Austin, where he was to remain for the rest of his life. While we are accustomed to peripatetic scientists, Cliff did manage to move considerably more than the rest of us. Some of these moves were related to changes in function, as I shall describe, and some were made for quite personal reasons. But I can't help but feel that Cliff acquired a considerable amount of restlessness when he remained in one place too long, the same kind of restlessness which I suspect made him change his primary activity so many times. 


\section{THE LABORATORY SCIENTIST}

When Cliff Morgan became Instructor at Harvard, at first working in Lashley's laboratory in the Biology building and later in Boylston Hall, he entered into a period of activity in which being a scientist was the most important thing he (or anyone else, for that matter) could do. He was largely a night worker, and he could be found in his laboratory almost any night of the week, into the wee hours of the morning. His research work there was largely carried out in collaboration with Harvard undergraduate students, including Robert McCleary, William Ober, and Eliot Stellar, but there was also a great interaction with fellow young faculty members, especially S. S. (Smitty) Stevens and Fillmore Sanford, the man who later became a brother-in-law through marriage when Cliff married Jean Snow, the sister of Fill Sanford's wife, Ann. Cliff had married earlier during graduate school days, but that marriage ended in divorce in 1946.

There were three main lines of research during this period of his life. One of them involved the analysis of the phenomenon of audiogenic seizures. The impetus for this research was N. R. F. Maier's research purportedly showing that rats would have "neurotic" seizures when apparently put into conflict by driving them off a jumping stand with a blast of air. Cliff demonstrated, in a series of papers, that the effect was not due to a neurotic conflict, but rather was due to high auditory frequencies, inaudible to man, in the blast of air.

Another line of research concerned hoarding behavior in rats, and he established, with a series of well-designed experiments, the way in which such behavior is controlled by the internal state of hunger in the rat and by the external environmental temperature: The third line of research, done largely in collaboration with Robert Galambos, was concerned with the effects of intensity on human pitch perception.

The truly remarkable thing about this facet of Cliff's life is how very short a time period it involved. He spent three years in graduate school, and then four more as Instructor at Harvard, and these were the only years in which he could be said to have laboratory science as his primary activity. During the last two years of the war, he was (as I mentioned before) a Technical Aide in the service of the war effort. Then he went to Johns Hopkins University, where I also went after the war, and he never had a fully functioning laboratory in all his years there. During the winter of 1946-1947, he and I collected some data on pitch-loudness relations, and these data were published in 1951, along with some data he had earlier collected with Bob Galambos at Harvard, as a joint paper: Morgan, Garner, and Galambos. To the best of my knowledge, this was the last active laboratory research he was engaged in.
But scientist he was for this period, and a truly excellent one. His reputation was already widespread by 1943 , and it was simply solidified by the publication of his first book, Physiological Psychology, in that year. This book, of course, quickly became a classic because it so systematized the field of physiological psychology. Thus, while the book was written to be a text, it was also very much a contribution to science.

How very strong his reputation was in these early years can best be seen by noting two dates. The first of these was his election to the Society of Experimental Psychologists in 1946, before Cliff had reached his 31 st birthday. At that time, in order to be elected to that august group, somebody had to retire, at age 60 , from membership to fellowship. I do not know whose retirement made Cliff's election possible, but I do know that nobody since that time has been elected at such a tender age. He had himself just become a Fellow in that Society in the year before his death, so he was an active member for half of his life. He would have chaired the meeting at the University of Texas in the spring of 1976 except for his death just a few weeks earlier. It was a function and honor that Cliff had looked forward to, since he had always been very active in that Society. The second date was his election in 1946 to be President in 1948 of the Division of Physiological and Comparative Psychology of the newly reorganized American Psychological Association.

Further evidence of the importance of his research during these early years can be found in the staying power of the research. I took the trouble of checking the Science Citation Abstracts for the year 1975. There were several references to Cliff's early research, all references to the original literature, not the secondary literature. So Cliff was recognized for his research achievements early, but the recognition has continued to this day, more than thirty years after he in fact did the research.

So the picture we have is of a young man totally dedicated to science, of the empirical variety, preferably laboratory, who had risen meteorically in his profession to a position of true eminence by his 30th birthday. I doubt that any of us who knew him well at that time would have correctly forecast the turns in his career that occurred in his later life. I, myself, certainly expected him to re-establish a laboratory at Johns Hopkins and to continue in the directions that he had been so successful in already. But new and different careers were in store for him. Perhaps he knew it, but I don't think so, because I lived through some of his inner turmoil while he was going through a second career in administration, and then into becoming primarily an author. These career changes were definitely not part of a carefully worked out life plan that Cliff himself knew of, much less the rest of us. These other things just happened because Cliff got 
involved in a new activity, accepted the challenge, and went about doing an excellent job.

\section{THE ADMINISTRATOR}

Cliff's first administrative position was as Technical Aide in the Office of Scientific Research and Development. Smitty Stevens had helped him get located in that position, and possibly already understood Cliff's tremendous talents for organization. His primary functions were to coordinate the activities of several research laboratories. This work did not require Cliff to be an active director of any particular laboratory, but Cliff himself effectively became a director before the war was over. He had seen the necessity for a laboratory which would focus on problems of shipboard communication and command systems, so in 1945 he arranged to set up a laboratory on the tip of Beavertail Island, at the mouth of Rhode Island's Narragansett Bay. This laboratory was manned with personnel begged, borrowed, or stolen from other wartime laboratories, and so never had a complement of personnel clearly its own. I was myself borrowed from the Psycho-Acoustic Laboratory at Harvard, and Leo Beranek, Director of the Electro-Acoustic Laboratory at Harvard, became the Director of the newly established Systems Research Laboratory, for that was the name carried by this laboratory for many years. Cliff, however, was de facto co-director of the laboratory, spending at least a couple of days a week there. So, by this time, Cliff had clearly moved into the supervisory aspects of administration, in addition to the coordinating aspects of it.

Up to this point it would be simple to argue that Cliff had simply strayed into administration, being led along by the inevitable forces of the disarranged lives we all led during those years. But now I shall remind you that he had committed himself to go to Johns Hopkins University in 1943, and that he was appointed in the Department of Biology there, because there was no Department of Psychology at Hopkins to be appointed to. I, too, along with several others, was initially appointed in Biology. Psychology as a department had been allowed to die during the Depression years, but Benjamin Willier, Chairman of Biology, wanted to start it up again, so he arranged for the initial appointments of psychologists in the Biology Department. But it was, even in 1943, absolutely inevitable that in due course there would be a Department of Psychology, and, with Cliff as its senior member, he was destined to become its chairman. So I must assume that he willingly anticipated the role of Chairman of Psychology when he first agreed to go to Hopkins.

Well, as so often happens, the inevitable did occur, and Psychology was made a separate department in 1946, with Cliff (by that time Associate Professor) as its Chairman. But in the meantime, what had Cliff been doing? At the end of the war, many of the wartime laboratories simply folded up, and the scientists who had been brought from all corners of the country simply scattered to their various corners. But the United States Navy decided that they didn't want to close the Systems Research Laboratory, which had been, in its short life, very successful in carrying out research on complex communications systems. They inquired of Harvard, which was the nominal sponsoring institution, whether they wanted to maintain it. Harvard said no, that they wanted to return to normal peacetime functioning. So where to go? Cliff was going to Johns Hopkins, and I had already committed myself to go there as well, so there was a nucleus of two people who had had active roles in the laboratory. (That was, incidentally, the largest nucleus of scientific personnel available in any one place. The scientists did indeed scatter.) So the Navy inquired of Hopkins whether it would agree to continue operating the Systems Research Laboratory. Hopkins agreed, and with Cliff as its Director. So, this administrative role Cliff actively sought; at least he could have avoided it. He remained its administrator for three years, by which time the Systems Research Laboratory had been moved from Rhode Island to Baltimore. I succeeded Cliff as Director of the Systems Research Laboratory in 1949, after a year of transition in which he remained as Director while I learned the job as Assistant Director.

In 1949 Cliff remained as Chairman of the Department of Psychology, bringing in many young men and building the department. He was a very good chairman, in the sense that he was extremely well organized, could lay out decision plans which were effective, could help the younger faculty get their careers started, and in general could run a tight ship. However, he had enormous conflicts about his role as administrator, and these conflicts began to build up on him at Hopkins. Some of these conflicts had to do with his own personality. He was very well organized, a trait which any of you who knew him well will recognize. However, he had very low tolerance for others who were not well organized, and could become quite agitated when he saw an ineffective process go on that could have been effective. Since universities, with their egalitarian and democratic ideas about how much control faculty should have in making decisions, are necessarily inefficient places, Cliff became more and more unhappy in his role as Chairman. He finally resigned as Chairman in 1954, and once again I succeeded him in an administrative post, becoming his replacement as Chairman of Psychology at Hopkins.

That was the end of his career as a university administrator, and he had learned enough about himself never to take on an administrative post at a university again. He continued to do what any of us would call administrative work, setting up and operating his own publication business. But he carefully avoided 
situations in which he had to function with people he considered administratively incompetent. In some respects Cliff was tolerant of his fellow man and woman, but not in matters of administrative efficiency.

\section{THE TEXTBOOK WRITER}

I have already noted that Cliff had been very successful in his first book, Physiological Psychology, published in 1943. A second edition of that book was published in 1950, this time with the co-authorship of Eliot Stellar. Still a third edition was published in 1960, this time once again under Cliff's sole authorship. Many of you undoubtedly first wet your feet in physiological psychology with one of these editions.

During Cliff's years at Hopkins, he increasingly turned his hand to other writing adventures. One of these came out of a series of lectures which the people working in the Systems Research Laboratory gave to the Naval Postgraduate School, then located in Annapolis. Actually, Alphonse Chapanis and II shared the lecture giving, even though Cliff wrote three of the lectures. Those lectures were turned into a textbook on Applied Experimental Psychology, with the authorship of Chapanis, Garner, and Morgan. This book, published in 1949, was the first textbook in that field, and once again was a very successful enterprise, the book remaining in press with the original publisher for over twenty years. During these years, Cliff also co-authored a book with James Deese, published in 1957.

But his major book-writing venture was his Introduction to Psychology. Cliff began this venture while he was still Chairman at Hopkins, and his approach to writing that book was typical of his approach to any major adventure, namely, an extreme emphasis on organization. And by this I mean organization of the venture, not just of the book. Cliff had the original chapters written by fourteen other authors, plus some initial contribution of his own. These authors were all at Johns Hopkins or had recently left Johns Hopkins. We had meetings to discuss the material, we read each other's chapters and made suggestions, and then Cliff rewrote much of the material, having reserved that right in the contractual arrangements, so as to produce a uniform style of writing. Then the artwork was added, by professionals, naturally. The next step was a trial run in two or three universities, to get comments that would allow still further improvements in the book. I don't think Cliff's basic mode of functioning was better exemplified than in the production of that book. This was not a book written from the heart, because of strong feelings about what ought to be said. It was a totally pragmatic venture and was approached in as businesslike a fashion as Cliff could manage. The book was published in 1956, three or four years after the first work was done on it.
The venture clearly succeeded. In fact, it was a huge success. It is also very difficult to disentangle this project with Cliff's decision to leave the chairmanship at Hopkins. He resigned as Chairman two years before the book actually appeared on the booksellers' stands, but by the time he resigned the book had become his primary activity. After he resigned as Chairman, he moved to the Eastern Shore of Maryland, and gradually decreased his functions within the Department. When the book did appear, and it became obvious what a success it was, Cliff also resigned his professorship, becoming a Fellow of the University in 1957, a purely courtesy title. Cliff had, by 1957, clearly established a new and different career for himself. He was no longer researcher and professor: He was a writer.

This book has now been through five editions, the later ones with R. A. King as co-author. It allowed Cliff to shape a career for himself much more to his liking because it made Cliff independently wealthy. Never again was Cliff to be dependent on a university for his salary. So Cliff became a free-roaming scientist, able to live and work where he wanted, with no problems of conflict about administrative work of the kind he had come to dislike so very much at Hopkins. Thus began a series of moves to other universities, in each case the decision being simply that Cliff would like to live and work there.

First came his move to Wisconsin in 1959. This move was initiated by the fact that David Grant was on leave for the year, but Cliff never had a formal appointment at Wisconsin. They would have been happy to give him a professorship, but he was not interested, because he wanted to maintain his freedom of choice. Nevertheless, he taught introductory psychology and other seminars, sat on student dissertation committees, and in all ways participated as a full faculty member, except that he carefully, and wisely, avoided all administrative work. When he left Wisconsin, after just three years, he turned some property over to the Department to furnish a faculty lounge, a lounge which will probably be named in his memory as of my last communication on the subject from Dave Grant. I myself kept contact with Cliff enough to know that he enjoyed those three years at Wisconsin. He was completely free of the irritating parts of the academic life, but continued doing those things which gave him pleasure. So I am not really sure why he left Wisconsin to go to Santa Barbara in 1962. But he did move and became a half-time Lecturer at the University of California at Santa Barbara for two years, going on leave the third year to fulfill some of his textbook commitments. Here the picture painted at Wisconsin was repeated. He taught two large introductory classes, served on various committees, and in general performed all that would be expected of a full-time faculty member, and all this with his usual efficiency. Here Cliff did toy with the idea of re-entering admini- 
stration by considering, for a while, the possibility of becoming Chairman at Santa Barbara. But that did not occur, probably fortunately for Cliff.

Cliff's name lives on at Santa Barbara because, repeating his gesture at Wisconsin, he donated a sum of money to the Department to establish what is now called the Clifford T. Morgan Colloquium Series. So at Santa Barbara, as at Wisconsin, Cliff gave considerably more than he took.

In 1967 Cliff moved to Austin, Texas, for one year being Visiting Professor and then becoming Adjunct Professor a year later, the title he held at his death. The specific reason for his move to Austin is much clearer than the reason for his move to Santa Barbara: His wife Jean's brother-in-law, Fillmore Sanford, a Professor at Texas, died, and Cliff went to help his wife's family. Cliff originally moved on a temporary basis, but later changed his mind and moved there permanently. Here again his functional role was repeated: He taught all kinds of courses, participated in selection of new faculty, and served on $\mathrm{PhD}$ committees. At Texas, however, Cliff carefully avoided faculty meetings or anything else smacking of administration. He never did get to like university administrative functions.

I have discussed these various moves of Cliff in this section because they are an integral part of the changed career pattern which Cliff's textbooks had made possible. Cliff had become primarily an author and sort of free-lance lecturer, a role much more to his liking.

\section{THE FIRST CHAIRMAN OF THE PSYCHONOMIC SOCIETY}

Of greatest interest to this group, probably, is Cliff's role in getting the Psychonomic Society founded. Here is the story, as reconstructed with considerable help from those involved, but especially with help from William Verplanck, who had the foresight to keep all of the early correspondence in which Cliff was involved.

The first germ of the idea of this organization came to life in a bar in Washington, at the meetings of the American Association for the Advancement of Science in December of 1958. That conversation was held by Cliff, William Verplanck, and Clarence Graham, and possibly somebody else whose identity got lost in the barroom atmosphere. The following summer Bill Verplanck was teaching at Wisconsin, and general discussions amongst the experimentalists at Wisconsin continued. The results of these discussions were that a letter dated July 4, 1959 was sent out to a number of people who were potential members of an organizing committee. This letter was signed by James Archer, Wilfred Brogden, J. C. Gilchrist, David Grant, Herschel Leibowitz, Fred Mote, Karl Smith, Willard Thurlow, Benjamin Wyckoff, and William Verplanck acting as the corresponding secretary for the Wisconsin group.

Cliff Morgan, who was about due to arrive at
Wisconsin himself, was one of the recipients of this letter, and replied to Bill Verplanck by return mail. In this letter he agrees to be a member of the organizing committee, suggests some more names for members, and suggests that Bill Verplanck become Acting Secretary of the Organizing Committee. There is a tone to this letter which intimates what actually happened: Cliff took charge, but with Bill Verplanck in a joint role in this activity. These things were happening very fast at that time, and by August 13 Cliff wrote to Bill Verplanck, including the following paragraph, which clearly states their joint roles: "Your offer to give up the secretaryship was most generous and complimentary. After thinking about this for some time, I think I would prefer that you hold onto the job but informally appoint me as a bylaws committee. In my experience, the bylaws represent the crux of getting a new organization going or an old one reorganized, and I think I would prefer to take on this part of the job. I have had some experience at it, drafting both the old Division 6 and new Division 3 bylaws as well as some for our Faculty and Division at Hopkins when we reorganized some years ago."

Cliff had indeed had such experience, and he really loved such organizing work. So he and Bill were in it to the hilt from that date onwards.

The Organizing Committee was formed and met, again at meetings of AAAS, this time in Chicago, December 1959, with Cliff as Acting Chairman and Bill Verplanck as Acting Secretary. The other members of the Organizing Committee were Brogden, Estes, Geldard, Graham, Humphreys, Neff, Spence, Stevens, and Underwood. This group decided to go ahead and start a new society, the date of this decision being December 31, 1959. The Organizing Committee was changed to the first Governing Board, Cliff Morgan was elected Chairman of the Governing Board, and Bill Verplanck its Secretary-Treasurer.

Invitations were sent to approximately 800 people who were invited to become Charter Members. The first meeting was scheduled to be held at the University of Chicago on September 1, 2, and 3,1960, just before the meetings of the American Psychological Association. The meetings were held, were a huge success, and the Psychonomic Society was on its way. The Society is, as you may have noticed, still functioning.

What about the name of this Society? I had myself always assumed that Psychonomic was a neologism, and that Cliff had had something to do with its invention. That is not so, however. In the months during which the group at Wisconsin was getting the Organizing Committee established, and in the early months of existence of the Organizing Committee itself, this embryonic society was known as the American Federation of Experimental Psychologists. Cliff had argued that the title was too long, and not very accurate either, since all research psychologists were to be 
included (not just experimentalists) and since the society was not in fact to be a federation of anything. So he and Bill Verplanck had felt that some new and hopefully compelling name would have to be found. Bill Verplanck, with the aid of some classicists, had discovered that there was an already existing word, "psychonomy," which meant "science of the mind," that seemed to fit the purposes. You may have to look the word up in a really large dictionary, but it does exist. So the Organizing Committee, by this time having become the first Governing Board of the Society, in the spring of 1960 decided on the name Psychonomic Society, just in time to send out the invitations for charter memberships.

So Cliff got what he had hoped for: a name with minimum appropriated connotations. But he did not get all that he had hoped for with this name, because he had also hoped that members of the Society would cease to be called psychologists, and would come to be called by a parallel but clearly differentiating name. At the first meeting of the Society, Cliff, as its first Chairman, began his remarks (he carefully avoided giving a presidential address) with: "Fellow psychonomists and psychonomers! Welcome to the first meeting of the Psychonomic Society."

It was a first annual meeting, and there have been many since. But we have not become psychonomers or psychonomists. I do not know why, except that the terms do seem awkward. But this was one dream of Cliff's that did not come to fruition.

Cliff, of course, is responsible for many of the characteristics of this Society, even as it functions today. In line with his original agreement to share functions with Bill Verplanck, Cliff did write the bylaws which with slight modification still determine how this Society functions. It was he also who wanted a Chairman of the Society, not a President, and who wanted the Chairman elected by the Governing Board and not by the total membership. The Governing Board itself is elected by the membership, but Cliff, with his characteristic concern for efficient operation, wanted to be sure that the chief officer of the Society would be selected for his or her ability to carry out a governing function. He did not want the position to become honorific, with people elected who were possibly great scientists but who had no sense of good administration. Cliff always did feel that the larger the decision-making body, the less apt it was to be efficient. So the small Governing Board selects its Chairman, who is the chief governing official, not necessarily the most honored person. I leave it to you to decide whether his hopes have been fulfilled, but I will state my own comment that this organization runs with fewer committees than any I have ever known.

For instance, the Membership Committee is simply a subcommittee of the Governing Board. Still further, there was to be no committee to evaluate papers to be given. If you were a member, then you were entitled to give a paper. As you know, the success of this Society has required some modification in these ideas. But the basic characteristic of it as primarily a scientific society, whose business is to run a scientific meeting, has certainly survived many pressures to change.

\section{THE EDITOR AND THE PUBLISHER}

Cliff Morgan wrote quite a large number of books, as I have already discussed. In addition, however, he was very active in various other aspects of the publishing business, being both an editor and a publisher. These skills, of course, have been of considerable benefit to this Society.

Even early in his career, when he was doing so much writing of his own, he was heavily involved in editorial work. He was Consulting Editor to McGraw-Hill's Series in Psychology from 1950 to 1959 , had been consulting editor to several journals, and was on the Editorial Board of the Annual Review of Psychology from 1953 to 1959. Still further, he was Chairman of the Publications Board of the American Psychological Association in 1960-1961, the very year in which the Psychonomic Society was born. In fact, he saw his experience in the Publications Board of the American Psychological Association as a valuable asset in understanding the publication needs of the new Society.

His change to a more active and directing role in publishing came when he took on the Editorship of Psychological Abstracts in 1960, for a three-year term during which he applied his organizing skills to coping with the vast problems of that journal. During all this period he was learning a great deal about the publishing and printing business, skills which were later brought to bear on the establishment of journals of special interest to members of the Psychonomic Society.

When this Society was formed, there was a clear understanding that, while the Society was not to engage in such activities as maintaining job-hunting services or even allowing equipment displays, there might come a time when the Society should enter the publishing business in order to maintain an adequate level of scientific exchange. In the early years of the Society, there was no attempt by the Society itself to begin publishing. But Cliff Morgan began the journal Psychonomic Science in 1964, while he was still at Santa Barbara, entirely on his own. His intent was to provide a more rapid means of publication for short scientific articles, along the lines of the journal Science. A year later, in 1965, he added Psychonomic Monograph Supplements, and then Perception \& Psychophysics in 1966, with Behavior Research Methods \& Instrumentation in 1969.

In 1968 Cliff offered the journals, and the whole business establishment necessary to publish and print the journals, to the Psychonomic Society, plus enough 
cash to see them through their early transition years. The actual transfer took place in 1970, and some changes in the structure of publications was made a year later. By 1973, Psychonomic Science became the Bulletin of the Psychonomic Society, Perception \& Psychophysics was continued, as was also Behavior Research Methods \& Instrumentation, and three new journals were added: Memory \& Cognition, Animal Learning \& Behavior, and Physiological Psychology. When the Society took over responsibility for these journals, it took specifically the responsibility for establishing editorial policy and for appointment of editors. Cliff, however, continued to manage the actual operations, becoming in effect publications manager for the Society. We had acquired a rather good thingjournals whose publication policies we could control, along with the man who had started the journals to continue running them from the entire business point of view. His loss to this Society is very real in regard to our publications.

This is my summary of the many facets of Clifford T. Morgan's professional life. I know of nobody who has played quite the role he has played both in contributing to experimental psychology and to the affairs of this Society. We cannot claim that this Society would never have come into existence without Cliff's guiding hand, because there were so many others involved in its founding. But I think we can claim that it would not have come into existence as soon as it did, as smoothly as it did, and with the same characteristics it still has, without Cliff Morgan's influence. His personality, his great need for and skill at efficient organization, all will continue to show in the character of this Society. We will miss him indeed. 